\title{
14
}

\section{Aid, Remittances and Foreign Direct Investment}

\begin{abstract}
Cilliers sheds light on the evolving global aid, investment and remittance landscape and what it means for Africa, with special attention to China's growing presence on the continent, and compares that with others. Collectively the EU and its member states provide most aid although the USA is Africa's largest single aid provider. Aid will remain important for lowincome countries but its importance is declining in favour of a focus on the need to attract larger volumes of foreign direct investment (FDI). An External Support scenario explores the impact of heightened aid, remittances and FDI on Africa's development trajectory.
\end{abstract}

Keywords Aid - Bilateral aid - China - The USA · EU • Concessional loans • Foreign direct investment (FDI) · Remittances · Trade · World Bank

\section{Learning Objectives}

- Understand China's involvement in African development, how and why it has evolved, comparing that with EU members and the USA

- Critically evaluate and compare the advantages and drawbacks of aid and foreign direct investment as development strategies

- Discuss the contribution and role of remittances. 
Africa and its people have received more aid than any other region in the world. From 1960 to 2018 the international community provided a cumulative amount of more than US $\$ 2.4$ trillion in aid to Africa. ${ }^{1}$ Asia and the Middle East, the other two regions that have historically received large amounts of aid, trail significantly behind Africa in total aid receipts. Today Africa gets about 32\% (US\$59.7 billion in 2017) of total global aid (US $\$ 190$ billion), slightly more than the amount that goes to Asia. But since Asia has almost four times the population of Africa, Africans receive much more aid per person than Asians, although the ratio is shifting towards Asian countries. $^{2}$

There are, however, a number of important problems with aid data. First, aid data often excludes China and sources differ widely in their calculations of the amount of Chinese money that qualifies as aid as opposed to loans. The China Africa Research Initiative estimates that China provided US $\$ 3$ billion globally in 2015 followed by a significant reduction to US $\$ 2.3$ billion in 2016. It is likely that the bigger portion of this amount went to Africa, but there is disagreement about how much of this would really qualify as aid rather than commercial loans. ${ }^{3}$

Second, until recently calculations of aid flows also excluded contributions from private sources like the Open Society Foundations of billionaire George Soros and the Bill \& Melinda Gates Foundation. The OECD's own largescale survey on global private philanthropy estimates flows of US $\$ 7.96$ billion per annum, which is equivalent to around five percent of government aid flows. Slightly less than a third of private donations goes to Africa. ${ }^{4}$

Actually, according to these estimates, China provides roughly the same amount of aid to Africa as the total from private aid sources.

\footnotetext{
${ }^{1}$ Calculated in IFs v7.465 and converted to constant 2018 dollars.

${ }^{2}$ As opposed to official aid, most private money flows to Africa (and elsewhere) goes to health and reproductive health in middle-income countries such as Nigeria and South Africa. OECD, 2018. Private Philanthropy Funding for Development Modest Compared to Public Aid, But Its Potential Impact Is High, Says OECD. [Online] Available at: http://www.oecd.org/dev/private-philanthropy-fun ding-for-development-modest-compared-to-public-aid-but-its-potential-impact-is-high.htm. Aid data taken from UNECA and WTO. 2019. An Inclusive African Continental Free Trade Area: Aid for Trade and the Empowerment of Women and Young People, Available at: www.tralac.org/documents/resources/cfta/2892-an-inclusive-afcfta-aid-for-trade-and-the-emp owerment-of-women-and-young-people-eca-wto-july-2019/file.html, p. 6.

${ }^{3}$ Kitano, N., 2017. A Note on Estimating China's Foreign Aid Using New Data: 2015 Preliminary Figures. Tokyo: JICA. Also see OECD, 2017. Development Co-Operation Report 2017: Data for Development. Paris: OECD, and China Africa Research Initiative, 2019. Data: Chinese Foreign Aid. [Online] Available at: http://www.sais-cari.org/data-chinese-foreign-aid-to-africa.

${ }^{4}$ OECD, 2018. Private Philanthropy Funding for Development Modest Compared to Public Aid, But Its Potential Impact Is High, Says OECD. [Online] Available at: http://www.oecd.org/dev/private-philan thropy-funding-for-development-modest-compared-to-public-aid-but-its-potential-impact-is-high.htm.
} 
These data issues aside, how intergovernmental financial institutions approach aid has undergone significant changes since the turn of the century.

Key milestones include the 2000 United Nations Millennium Summit in New York, which put aid to Africa in the spotlight after it had gone out of favour in previous years; the Report of the Commission for Africa released in 2005 that was spearheaded by then UK Prime Minister Tony Blair; as well as the European Consensus on Development - an EU policy declaration on aid-also issued in that year. Collectively these efforts paved the way to the 2005 World Summit in New York, which called for increased aid transfers in order to reach the eight Millennium Development Goals set in 2000. Key among its goals was to halve poverty and hunger by 2015 .

Actually the push to halve poverty by 2015 was met five years ahead of the deadline largely on the back of rapid economic growth and pro-poor policies in China, which had little to do with aid. ${ }^{5}$ Rapid economic growth in China saw the number of people living in extreme poverty fall from 1.9 billion in 1990 to 836 million in 2015. The target to halve the portion of people suffering from hunger was narrowly missed, however, as were a number of other Millennium Development Goals. ${ }^{6}$

A key development on the road to the final year of the 2015 MDG goal was the 2011 Busan Partnership for Effective Development Cooperation (named after the city in South Korea that hosted the final meeting), which established, for the first time, an internationally agreed-upon framework for development cooperation that included traditional and new donors from the South, civil society organisations and private philanthropy. Under the Busan commitments, donors agreed to untie aid to allow recipients to use their aid dollars to procure from the cheapest suppliers and not those prescribed by donors - an issue that aid advocates had been lobbying for decades - as well as various other measures that harmonised aid modalities among donor countries.

These reforms, among others, precipitated more effective aid that was, henceforth, increasingly being channeled towards low- and lower-middleincome countries, where the majority of poor people are to be found, rather than towards upper-middle-income countries. Whereas, if aid were distributed equally among African countries, it would equate to about $2.5 \%$ of GDP, these reforms would see aid to low-income countries increase to ten percent of GDP-equating to more than $50 \%$ of government revenue.

\footnotetext{
${ }^{5}$ Aid has a modestly positive effect on growth with an average internal rate of return of around $10 \%$. ${ }^{6}$ Ritchie, H., and Roser, M., 2018. Now It Is Possible to Take Stock-Did the World Achieve the Millennium Development Goals? 20 September 2018. [Online] Available at: https://ourworldindata. org/millennium-development-goals.
} 
In contrast, aid as a percent of government revenue in lower-middle-income African countries dropped to below ten percent and below one percent in upper-middle-income countries, illustrating the progress that has been made in shifting aid to where the need is greatest.

Since North African countries have long since graduated to middle-income status, by 2017 more than $90 \%$ of the aid to Africa went to Sub-Saharan Africa. $^{7}$

On average, approximately $70 \%$ of aid is provided bilaterally and the balance through multilateral channels. Bilateral aid is provided directly from a national agency such as the US Agency for International Development (USAID) or the Swedish International Development Cooperation Agency (SIDA) to the country or region concerned. Multilateral aid is provided through organisations such as the UN Development Programme (UNDP), the World Bank and the African Development Bank. The latter are able, through aid, to provide grants as well as concessional loans to African countries at below market rates.

Aid serves as an important avenue through which external partners can augment governments' ability to meet the most pressing needs of their populations, and will remain critical for Africa's low-income countries for at least a next decade. For example, aid boosted government revenues in low-income Africa by an astounding ten percentage points in 2018. In a country such as Ethiopia, donors provided US\$600 million in health funding in 2015, accounting for roughly half of the total health spending in the country. ${ }^{8}$ Here aid has enabled rapid improvements in maternal and infant mortality rates. These improvements have in turn accelerated Ethiopia's demographic transition and will have a substantive positive impact on the nation's long-term future development prospects.

\section{The Shifting Global Aid Landscape}

The USA remains Africa's single largest bilateral aid donor, but provides significantly less aid than the EU and its member states and aid from the USA is declining. The trend is similar to the weakening US trade relations with Africa that were examined in Chapter 11.

\footnotetext{
7OECD, 2019. Development Aid at a Glance: Statistics by Region. 2. Africa 2019 Edition. [Online] Available at: http://www.oecd.org/dac/financing-sustainable-development/development-fin ance-data/Africa-Development-Aid-at-a-Glance-2019.pdf, p. 2.

${ }^{8}$ The Federal Democratic Republic of Ethiopia Ministry of Health. 2015. Ethiopia Health Sector Transformation Plan. Available at: www.globalfinancingfacility.org/sites/gff_new/files/docume nts/HSTP\%20Ethiopia.pdf.
} 
The EU and its member states provide about half of all aid to Africa (about $€ 20$ billion per annum) and the USA about 24\%.?

In response to domestic and international affairs alike, the USA' primary interests in the African continent have evolved. After 9/11, its focus shifted to the war on terror, culminating in the disastrous Western interventions in Iraq and Libya that have destabilised the Middle East and North Africa. Then the shale energy revolution has reduced America's dependence on imported oil that previously determined its relationship with oil-producing countries like Nigeria and Angola. Lately it has also started to draw down on its military engagement on the continent but the USA will retain an important role in providing humanitarian support as public support for this role remains stronger than for aid. The USA' escalating competition with China, domestic political divisions and trade disputes with friend and foe alike under the Trump presidency led to an incoherent and distracted policy towards Africa.

Most large donors are redoubling their efforts to push for a larger role for the private sector. For example, after several years of inaction the Better Utilisation of Investments Leading to Development (BUILD) Act (passed in the US Senate in October 2018) supports private investment. ${ }^{10}$ In addition, the newly established US International Development Finance Corporation (USIDFC) will be able to invest up to US\$60 billion in Africa, focusing on small- and medium-sized enterprises and support to local companies. ${ }^{11}$

BUILD was established as part of the Trump administration's Prosper Africa initiative that, according to former US National Security Advisor John Bolton, 'will support US investment across the continent, grow Africa's middle class, and improve the overall business climate in the region' ${ }^{12}$ Launched on 13 December 2018, Prosper Africa is aimed at helping US companies navigate the US bureaucracy and enable them to benefit from its various programmes and services. Its primary aim is therefore to open markets

\footnotetext{
${ }^{9}$ The Africa-EU Partnership, https://www.africa-eu-partnership.org/en/about-us/financing-partnership. ${ }^{10}$ The BUILD Act replaces the Overseas Private Investment Corporation (OPIC) that was created in 1971.

${ }^{11}$ The USIDFC will be able to take a minority equity stake or financial interests of its own in development projects. USIDFC will also provide insurance or reinsurance services, technical assistance, administer special projects, establish enterprise funds, issue obligations, and charge and collect service fees. 'Through these market-based fees, the USIDFC will operate at no net cost to [US] taxpayers'. Runde, D. F., and Bandura, R., 2018. The BUILD Act Has Passed: What's Next? [Online] Available at: www.csis.org/analysis/build-act-has-passed-whats-next.

12Airey, J., 2018. Bolton: New Africa Strategy Is Tough On China, Russia, U.N. [Online] Available at: www.dailywire.com/news/39347/watch-bolton-new-africa-strategy-tough-china-jacob-airey.
} 
for American businesses, and, in that process, to enable the USA to compete with China in Africa. ${ }^{13}$

It is unlikely that Europe will follow US disengagement with Africa. Europe remains connected with Africa through shared histories, languages and physical proximity. The EU has also been diligent in nurturing a collaborative and consultative relationship with Africa over successive decades. And whereas the USA is cautious if not dismissive of regional organisations such as the African Union and the various regional economic communities, the EU often sees them as its primary point of engagement that reflect its own economic and political architecture. Decades of European investment in building the capacity of the African Union as well as relationships of aid and trade have created a network of friendship and collaboration that remains important for both parties although Brexit and widespread anti-migrant sentiments across Europe are undermining the strength of this relationship.

For instance, without European assistance, the African Union's muchvaunted African Peace and Security Architecture (APSA) would not have been able to establish its three (out of an envisioned five) brigade-size capabilities for conflict prevention and management in South, West and East Africa. Since 2004, the European Union (EU) has spent more than $€ 3.5$ billion of its aid commitment to support APSA and various peace support missions in Africa. ${ }^{14}$

The EU's intent to move beyond a donor-recipient relationship towards a more mature engagement was first captured in the comprehensive Joint Africa-EU Strategy (JAES) of 2007 that was adopted by the Heads of State and Government of the African Union and the EU at their second EU-Africa Summit in Lisbon. The most recent (third) JAES plan of action outlines four strategic areas from 2018 onwards: investing in people-education, science, technology and skills development; strengthening resilience, peace, security and governance; migration and mobility; and mobilising investments for sustainable structural transformation. Subsequently, at the 5th African Union-European Union Summit, the partners agreed that economic investment, job creation and trade were common priorities that require a joint commitment.

In line with the latter goal, in 2017 the EU launched its External Investment Plan (EIP) that includes a new guarantee mechanism where aid is used to mobilise private capital flows through 'blended arrangements' and

\footnotetext{
${ }^{13}$ Runde, D. F., and Bandura, R., 2019. U.S. Economic Engagement in Africa: Making Prosper Africa a Reality. Washington: Center for Strategic \& International Studies.

${ }^{14}$ European Commission, 2020. Questions and Answers: Towards a Comprehensive Strategy with Africa, 9 March 2020, https://ec.europa.eu/commission/presscorner/detail/en/qanda_20_375.
} 
the provision of guarantees to mobilise additional resources for investment in Africa. ${ }^{15}$ That was followed, in 2018, with the announcement of a new Africa-Europe Alliance for Sustainable Investment and Jobs. The intention is that the EU-AU Summit originally scheduled for October 2020 but then delayed due to COVID-19, will approve partnerships in five key areas: green transition; digital transformation; sustainable growth and jobs; peace and governance; and migration and mobility. ${ }^{16}$

Considerable attention is being given to efforts such as Aid for Trade and arrangements to mobilise additional financial support to the region in the form of loans or equity. ${ }^{17}$ Aid for Trade uses a portion of aid (US $\$ 13.3 \mathrm{bn}$ of US\$59.7 bn total aid to Africa in 2017) ${ }^{18}$ to build trade capacity in poor countries and on improving trade diversification and helping economically marginalised groups.

On the Current Path forecast, Africa will receive US\$102 billion net aid in 2030 and US\$124 billion in 2040. Most of the increase will (and should) go to low-income countries that are expected to experience a doubling of aid to US $\$ 85$ billion by 2040 , although, as a portion of GDP the contribution of aid to these countries will decrease from its current $10 \%$ to $5.7 \%$. The reason for the decline in aid as a portion of GDP is, of course, due to the rapid economic growth that most of these countries will experience, in part because they all have young and fast-growing populations.

The expected near doubling of aid in constant dollar amounts would be significantly larger if developed countries met the $0.7 \%$ of gross national income (GNI) target for aid contributions as set out in the SDG ambition. ${ }^{19}$

\footnotetext{
${ }^{15}$ Its thematic objectives are (i) local private sector development, (ii) social and economic infrastructure development, (iii) climate change mitigation and (iv) root causes of migration and, in addition to financial support, it provides technical assistance and offers a policy dialogue. Gavas, M., and Timmis, H., 2019. The EU's Financial Architecture for External Investment: Progress, Challenges, and Options. CGD Policy Paper 136, pp. 1-2. Also European Commission, n.d. Joint Africa-EU Strategy. [Online] Available at: https://ec.europa.eu/europeaid/regions/africa/continental-cooperation/ joint-africa-eu-strategy_en.

${ }^{16}$ EU Press Release, 2020. EU Paves the Way for a Stronger, More Ambitious Partnership with Africa, 9 March 2020 [Online]. Available at: https:/lec.europa.eu/commission/presscorner/detail/en/ IP_20_373.

17The Aid for Trade Initiative was formally launched at the Sixth WTO Ministerial Conference in Hong Kong in 2005. See World Trade Organization, 2019. Aid for Trade. [Online] Available at: www.wto.org/english/tratop_e/devel_e/a4t_e/aid4trade_e.htm.

${ }^{18}$ Calculated from UNECA and WTO. 2019. An Inclusive African Continental Free Trade Area: Aid for Trade and the Empowerment of Women and Young People. Available at: www.tralac.org/documents/resources/cfta/2892-an-inclusive-afcfta-aid-for-trade-and-the-emp owerment-of-women-and-young-people-eca-wto-july-2019/file.html, p. 6.

${ }^{19}$ United Nations, n.d. Goal 17: Revitalize the Global Partnership for Sustainable Development. [Online] Available at: www.un.org/sustainabledevelopment/globalpartnerships/.
} 
That is unlikely and the increase in the amount of aid within the International Futures forecasting platform (IFs) is driven by the rapid growth in the economies of donor countries rather than any increases in the aid as a percent of GDP by donors. Much more realistic is to expect that aid, as a portion of the GDP of rich countries will remain stable or, more likely, moderately decline. As countries become wealthier they tend to also become more stingy.

The COVID-19 crisis will also impact upon aid. The initial reaction may be to shift all resources closer to home and to reduce aid or spend it on housing or deterring migrants as was the case recently. The longer-term impact of COVID-19 will be to increase poverty and hence migrant flows to Europe in particular. Inevitably partners will be forced to consider how best to improve the ability of African governments to constrain migration and that may, in time, modestly increase rather than decrease aid flows.

\section{Leveraging Foreign Direct Investment for Africa}

As countries develop, aid inevitably diminishes in importance and aidproviders inevitably focus on increasing the role of the private sector, in line with the adage that trade follows aid. In the process, foreign direct investment (FDI) becomes an important tool through which governments can unlock additional private-sector capacity and grow the economy of the recipient country more rapidly. The intention is that aid recipients steadily be weaned off aid.

FDI is essentially a long-term investment made by a company in one economy or country in another-a definition that distinguishes it from more volatile foreign portfolio investments. It is typically discussed as consisting of a stock of investment that has been built up (or that is depleted) through annual in- or outflows. FDI has many advantages, some of which were examined in Chapter 11 that dealt with trade. Because FDI typically involves the transfer of technology, capacity and skills from a multinational (or mother) corporation to an affiliate in the host country, FDI is broadly viewed as the best way to stimulate economic development and the private sector as the best vehicle to implement the associated projects and services. ${ }^{20}$

Domestic factors, generally discussed as the absorptive capacity of recipient countries, are often a determining factor in translating FDI inflows into growth and development. And generally it seems that 'the growth gains from

\footnotetext{
${ }^{20}$ See, for example: Bjorvatn, K., Kind. H. J., and Nordas. H. K., 2002. The Role of FDI in Economic Development. Nordic Journal of Political Economy, pp. 109-126. http://www.nopecjour nal.org.
} 
FDI are unlocked only when the host country has reached a certain optimal level of financial development ... and in countries with a minimum threshold level of human capital stock'. ${ }^{21}$

The advantages of seeking to attract larger portions of FDI appear selfevident when one considers the large potential pool: globally insurance companies, pension funds and sovereign wealth funds have more than US $\$ 100$ trillion in assets under management. ${ }^{22}$ Africa needs a very small fraction of these amounts to plug its large infrastructure financing gap, for example.

Private-sector investment is, however, not a substitute for efforts by national governments or contributions from the public sector or multilateral development banks, which are critical to the development of large, basic infrastructure, such as water and sanitation systems. Historically most private financing in Africa has occurred in the information and communications, renewable energy and transport sectors, but not in these core infrastructure. The reason is self-evident-returns on large infrastructure development often take decades to materialise and may even require ongoing subsidies.

Most research and efforts to encourage private-sector investment to build basic infrastructure gloss over its shortcomings that include much higher interest rates than those of public or multilateral creditors (such as the World Bank and International Monetary Fund) while maturities (lending periods) are typically also significantly shorter. Most private financiers also lack a development mandate, looking instead to maximise profit, and are reluctant to invest in the early stages of infrastructure development where the need is most severe. They inevitably tend to cherry-pick the projects that they are prepared to fund and are generally risk-averse. Meanwhile, concessional financing available to Africa has declined. The result is that, in 2017, only $2.8 \%$ of infrastructure commitments in Africa came from the private sector. $^{23}$

In addition to national governments that provided roughly $42 \%$ of funds for infrastructure, Africa generally has to look to financial institutions such as the World Bank and the African Development Bank or state-backed lending

\footnotetext{
${ }^{21}$ Yeboua, K., 2019. Foreign Direct Investment, Financial Development and Economic Growth in Africa: Evidence from Threshold Modeling, Transnational Corporations Review, https://doi.org/10. 1080/19186444.2019.1640014, pp. 2-3.

${ }^{22}$ Rabah, A., Bolton, P., Peters, S., Sanama, F., and Stiglitz, J. 2017. From Global Savings Glut to Financing Infrastructure. Economic Policy 32, pp. 221-261.

23Prinsloo, C., 2019. The Pitfalls of Private Sector Investment in Infrastructure Financing. SAIIA Policy Briefing No. 187, June 2019. Available at: https://saiia.org.za/research/the-pitfalls-of-privatesector-investment-in-infrastructure-financing/; Alley, I., 2017. Capital Flow Surges and Economic Growth in Sub-Saharan Africa: Any Role for Capital Controls? African Development Bank Group Working Paper Series 252, March 2017.
} 
from a country with deep pockets such as China to fund its infrastructure deficit. ${ }^{24}$ China has a number of additional advantages when it comes to building large infrastructure projects in Africa: it largely operates on a government-to-government basis instead of private sector to private sector approach; boasts significant finances to invest since it has consistently had a positive balance of trade since 1990' and has massive overcapacity and significant domestic experience in building infrastructure such as roads and railways. None of these advantages are readily available from the USA or Europe.

This does not mean that private investment in infrastructure from these other sources does not occur. Rather, the associated return on investment needs to be high enough to attract the private sector. That typically only happens in the case of oil, gas and other commodities. For example, in June 2019 , the USA energy firm Anadarko Petroleum Corporation ${ }^{25}$ gave the goahead for the construction of a US $\$ 20$ billion gas liquefaction and export terminal in Mozambique - the single largest liquid natural gas project in Africa and an amount equivalent to almost half of total FDI to Africa in 2018. By the end of 2019, total investments in Mozambique for the next decade were estimated at US $\$ 128$ billion-more than the entire amount of aid and FDI to all of Africa in $2018 .^{26}$

Prior to that uptick, FDI flows to Africa peaked at 3.8\% of GDP in 2008 at the start of the global financial crisis, and declined thereafter. By 2017, FDI had recovered to three percent of GDP or US\$42 billion-a fraction of the US $\$ 476$ billion that went to developing Asia. But then the African economy is only $14 \%$ the size of developing Asia. ${ }^{27}$ Historically Africa has received less FDI as a percent of GDP than a region such as South America. For several years China started to buck that trend, but its attention is currently shifting closer to home, particularly regarding the implementation of the Belt and Road Initiative in Asia. The COVID-19 crisis will inevitably see FDI flows to Africa decline sharply in 2020, also possibly for subsequent years.

\footnotetext{
${ }^{24}$ In 2017 China provided 23.8\% of Africa's infrastructure commitment. Prinsloo, C., 2019. The Pitfalls of Private Sector Investment in Infrastructure Financing. South African Institute of International Affairs, Policy Briefing No. 197, June 2019 [Online] Available at: https://saiia.org.za/research/ the-pitfalls-of-private-sector-investment-in-infrastructure-financing/.

${ }^{25}$ Zawadzki, S., 2019. Anadarko Approves \$20 Billion LNG Export Project in Mozambique. Reuters. 18 June 2019. Available at: www.reuters.com/article/us-mozambique-anadarko-lng/anadarko-approves20-billion-lng-export-project-in-mozambique-idUSKCN1TJ2DI.

${ }^{26}$ Sasha Planting, Gas in Mozambique-A \$128bn Opportunity, Business Maverick, 24 September 2019, https://docs.google.com/document/d/1kNSyt_v7NmK2S8W5L7iEogw4Jv1Oi7CwlhZ_yYVnl_ o/edit\#.

27United Nations Conference on Trade and Development, 2018. Regional Fact Sheets. [Online] Available at: https://unctad.org/en/Pages/DIAE/World\%20Investment\%20Report/Regional-Factsheets. aspx.
} 
To access capital markets in the West, countries need a sovereign credit rating by an international rating agency to independently evaluate its creditworthiness. In mid-2019 the only African countries with a sovereign credit rating by all three key international rating agencies (Moody's, Standard \& Poor's and Fitch) were Angola, Egypt, South Africa and Morocco and it is perhaps no surprise that the majority of FDI goes to these countries. ${ }^{28}$ These considerations are, of course, less significant in the case of state-backed loans from a country such as China-although the latter are seldom offered at concessional rates.

In addition to being the largest national provider of aid to Africa, the USA also leads on the stock of FDI that has built up from any single country although recent inflows have declined. It is followed by the United Kingdom and France. Investments by South Africa in the rest of Africa have also expanded rapidly. However, when comparing the stock of FDI from all EU member states with the USA and China, the former accounts for $40 \%$, the USA for seven percent and China for $5 \% .{ }^{29}$

The slow pace of post-2008 rates of growth in FDI globally were temporarily affected when, at the end of 2017, the Trump administration introduced tax reforms that allowed the large-scale repatriation of accumulated foreign earnings by US multinationals. Global foreign direct investment temporarily plummeted-except in Africa, where it remained surprisingly resilient—amounting to US $\$ 46$ billion in 2018 but is still below the US $\$ 50$ billion average of the previous ten years.

More broadly, FDI to Africa has slowed in recent years, largely due to the impact of the Arab spring and declining oil prices that have seen economic stagnation in Libya, Algeria, Egypt and Tunisia, and placed the economies of countries such as Angola and Nigeria under tremendous strain. Domestic policies have also played a role in South Africa, traditionally a large recipient of FDI, where a raft of controversial policies on land and investment agreements undermine investment confidence. ${ }^{30}$

\footnotetext{
${ }^{28} \mathrm{~A}$ further 13 countries were rated by two of the three agencies, namely Botswana, Republic of Congo, Cameroon, Cape Verde, Ghana, Kenya, Namibia, Nigeria, Rwanda, Senegal, Tunisia, Uganda and Zambia. See Country Economy, n.d. Sovereigns Ratings List. [Online] Available at: https://countr yeconomy.com/\%20ratings.

${ }^{29}$ European Commission, 2018. Africa-Europe Alliance. [Online] Available at: https://ec.europa.eu/ commission/africaeuropealliance_en. This data would still include the UK as a member of the EU.

${ }^{30}$ UNCTAD, 2018. World Investment Report: Investment and New Industrial Policies. New York and Geneva: United Nations Publication. Available at: https://unctad.org/en/PublicationsLibrary/wir 2018_en.pdfand; UNCTAD, 2019. World Investment Report: Special Economic Zones. New York and Geneva: United Nations Publication. Available at: https://unctad.org/en/PublicationsLibrary/wir 2019_en.pdf, p. x.
} 
Against this background state-led infrastructure investments from China have become particularly important for Africa.

\section{China's Growing Footprint in Africa}

A recent study indicates that China has pumped more than US $\$ 72$ billion worth of FDI into Africa between 2014 and 2018, followed by France (US $\$ 34.17$ billion), the USA (US $\$ 30.85$ billion), United Arab Emirates (US $\$ 25.27$ billion) and the United Kingdom (US\$17.68 billion). Other key investors on the continent are South Africa (US\$10.18 billion), Germany (US $\$ 6.88$ billion), Switzerland (US\$6.43 billion), India (US\$5.4 billion) and Spain (US $\$ 4.38$ billion). ${ }^{31}$ Africa is the third largest destination for Chinese investment after Asia and Europe, although investment in Sub-Saharan Africa slightly declined in 2017 following a drop in aggregate Chinese investment. ${ }^{32}$ In a comprehensive study on China in Africa published in June 2017, the Mckinsey Global Institute concludes that 'the Africa-China opportunity is larger than that presented by any other foreign partner - including Brazil, the European Union, India, the United Kingdom, and the United States'. ${ }^{33}$

The authors set out two scenarios. In the first scenario revenues of Chinese firms in Africa grow from US $\$ 180$ billion to around US\$250 billion in 2025. A second scenario sees Chinese firms in Africa expand aggressively in both existing and new sectors, achieving revenues of US\$440 billion in 2025. Before COVID-19 FDI flows to Africa was on track to return to increases of around $15-20 \%$ per annum.

The IFs Current Path forecast is that inflows from FDI to Africa will increase from its current $3.1 \%$ of GDP per annum to around $3.9 \%$ by 2040-roughly equivalent to the size of the African economy as a portion of the global economy. This will be a continuation of a trend that has seen FDI flows overwhelmingly go to Asia. Clearly much more needs to be done

\footnotetext{
${ }^{31}$ As reported by James Anyanzwa, 2019. China Injects $\$ 72 \mathrm{~b}$ in Africa as Its Continental Influence Gathers Pace. The East African, 9 October 2019, www.theeastafrican.co.ke/business/China-injects72b-in-Africa-as-its-influence-gathers-pace/2560-5303134-10sv8vf/index.html?utm_source=Media+ Review+for+October+9\%2C+2019\&utm_campaign=Media+Review+for+October+9\%2C+2019\& utm_medium=email. Accessed 14 October 2019.

${ }^{32}$ American Enterprise Institute, 2019. China Global Investment Tracker. [Online] Available at: http:// www.aei.org/china-global-investment-tracker/; Jayaram, K., Kassiri, O., and Sun, I. Y., 2017. The Closest Look Yet at Chinese Economic Engagement in Africa. [Online]. Available at: www.mckinsey.com/ featured-insights/middle-east-and-africa/the-closest-look-yet-at-chinese-economic-engagement-in-africa. ${ }^{33}$ Jayaram, K., Kassiri, O., and Sun, I. Y., 2017. The Closest Look Yet at Chinese Economic Engagement in Africa. [Online] Available at: www.mckinsey.com/featured-insights/middle-east-and-africa/theclosest-look-yet-at-chinese-economic-engagement-in-africa.
} 
to increase flows to Africa though the steady increase in tensions between the USA and China may reward Africa.

Africa has already benefited significantly from China's remarkable economic transition over the last two decades, first through its demand for commodities, second from China's positive balance of payments (in other words, it had funds to invest) and finally from China's coordinated effort to export its surplus construction capacity that eventually led to the Belt and Road Initiative. The latter has gone through various name changes since its announcement in 2013. Africa, which was not part of the original scheme, was only included in 2015 as it and other regions clamoured to benefit from potential investments in infrastructure.

Investments inevitably require collateral-pointing to another advantage for China, which has proven more flexible in accepting 'non-traditional' collateral. In fact China's willingness to accept airports, harbours and future commodity exports (or even mines) as security has raised alarm bells in conservative circles in the USA who see this as a ploy through which China can lay its hands on strategic infrastructure with potential security implications. This complaint is, however, seldom a concern in Africa and not borne out by deeper analysis although there have been many number of instances in which African governments have been induced to enter into expensive prestige projects (such as the airport in Lusaka) and overpriced railway lines (such as the Mombasa-Nairobi standard gauge line). And then there is the Chinese habit of trying to tie countries into agreements where it pays for commodities by offering the services of Chinese companies such as with Angola and South Sudan. Today Angola has a debt-to-GDP ratio of $91 \%$, half of which is owed to China and guaranteed by oil. ${ }^{34}$

But there is also clear evidence of rising concerns in Beijing about the ability of key African governments to service their loans from China.

A more serious concern that has often been repeated in mainstream media is that many of the large Chinese construction (and other) projects apparently provide little work for locals. That may have been the situation several years ago but research based on extensive field research in Ethiopia and Angola ${ }^{35}$

\footnotetext{
${ }^{34}$ The Challenges of Reform in Angola (2020) Africa Center for Strategic Studies, 21 January 2020 and Staff writer (2020) Angola negotiates the end of oil-backed debt with China, 23 January 2020, Macauhub, https://macauhub.com.mo/2020/01/23/pt-angola-negoceia-com-china-fimde-petroleo-como-garantia-para-divida/.

${ }^{35}$ Oya, C., and Wanda, F. 2019. Working Conditions in Angola. Infrastructure Construction and Building Materials Factories. Angola Research Brief, SOAS, University of London. [Online] Available at: www.soas.ac.uk/idcea/publications/reports/file141347.pdf; Schaefer, F., and Oya, C., 2019. Employment Patterns and Conditions in Construction and Manufacturing in Ethiopia: A Comparative Analysis of the Road Building and Light Manufacturing Sectors. IDCEA Research Report,
} 
indicate that national labour participation is substantially higher than generally assumed in Western media, that wages in Chinese firms abroad are largely similar to other firms in the same sector and that Chinese firms contribute as much to training and skills development as other companies in the same sector.

Then there is the issue of the quality of infrastructure, which is often quite poor, and the extent to which China is 'exporting corruption' in the manner in which it uses development assistance to buy influence (and contracts) from African leaders. Nor are these companies able to be held to account domestically in China through shareholder activism or public disclosure.

The problem with the quality argument, borne out by my many travels across Africa, is that Africans generally get what they pay for (low quality at low prices) and that an argument can be made that much is of 'appropriate' quality.

This brings us to the most important difference between Chinese and Western practices: large Chinese loans do not come with a requirement to discuss matters around the rule of law, good governance or human rights as done by the IMF and the World Bank. China does not share the views and approaches of the West in terms of rule of law and transparency and competitive tendering as an antidote to corruption and what has generally become known as 'standards of good governance'. Like US and European practices pf some decades ago, it has little qualms about leaning on African governments and offering inducements such as recently happened in Uganda where longstanding President Museveni intervened in a bidding process for a contract to surface the highway linking Kampala to Jinja by noting that he had identified the appropriate investor, China Railway 17th Bureau Group Company. ${ }^{36}$

China has deep pockets and, 'through its major policy banks, state-owned commercial banks, and government agencies—now represents the largest official external creditor to developing country governments worldwide'. ${ }^{37}$ It ran a year-on-year positive trade balance for decades with the result that total overseas lending from China's two main policy banks amounted to US\$675

\footnotetext{
SOAS, University of London. [Online] Available at: www.soas.ac.uk/idcea/publications/reports/file14 1205.pdf.

${ }^{36}$ Muhumuza, R. 2019. As China Builds Up Africa, Some in Uganda Warn of Trouble, AP News, 24 October 2019, https://apnews.com/62ab13badad04dd7b38a69b69eac61d1?utm_source=Media+ Review+for+October+24\%2C+2019\&utm_campaign=Media+Review+for+October+24\%2C+2019\& utm_medium=email.

${ }^{37}$ Morris, S., Parks, B., and Gardner, A., 2020 Chinese and World Bank Lending Terms: A Systematic Comparison Across 157 Countries and 15 Years. Policy Paper 170, Center for Global Development, 2 April 2020. [Online]. Available at https://www.cgdev.org/publication/chinese-and-world-bank-lendingterms-systematic-comparison.
} 
billion at the end of 2016-already more than twice the size of World Bank loans although a very modest portion of this goes to Africa. ${ }^{38}$

At the time that COVID-19 came to the continent Chinese lending to Africa was already set to decline amid concerns about high debt levels in Africa. In fact, Africa is steadily moving down the Chinese list of priorities as its economy transitions away from infrastructure investment and commodity dependence towards domestic consumption.

The change could have an important impact in Africa since China has become the biggest single country funder and builder of infrastructure projects in Africa, having spent about US $\$ 11.5$ billion per annum since 2012. ${ }^{39}$ China is therefore the largest contributor in helping to fill Africa's gap in infrastructure, which the African Development Bank estimates at anything between US $\$ 130$ and US $\$ 170$ billion annually. ${ }^{40}$

In addition to the visible, large, state-led infrastructure companies from China active on the continent, McKinsey estimates that more than 10,000 privately owned small Chinese companies operate in Africa. This number is substantially higher than official data from China's Ministry of Commerce. McKinsey concludes that China's engagement in Africa is 'unparalleled' and that the true picture is understated with total financial flows around 15\% higher than official figures convey. ${ }^{41}$

Infrastructure is not the only (Chinese) game in town. To ease the longrunning pressure on the naira after it steadily lost value against the US dollar since 2015, Nigeria began selling Chinese renminbi (yuan) to local traders and businesses. The move has made it easier for local businesses in Nigeria to trade and engage with their Chinese counterparts without the need of first converting their local currency to dollars. After the 2015 drop in global oil prices Nigeria faced a major dollar shortage and its foreign reserves dwindled. Setting up the renminbi as an alternative trading currency eases all of this, although China's conditions and requirements to access funding and

\footnotetext{
${ }^{38}$ Neuweg, I., 2018. What Types of Energy Does China Finance with Its Development Aid?. [Online] Available at: http://www.lse.ac.uk/GranthamInstitute/news/china-energy-development-aid/.

39 Partington, R., 2019. Fears Grow in Africa That the Flood of Funds from China Will Start to Ebb. [Online] Available at: www.theguardian.com/business/2019/jan/05/africa-fears-grow-flood-fundschina-start-to-ebb?utm_source=Media+Review+for+January+7\%2C+2019\&utm_campaign=Media+ Review+for+January+7\%2C+2019\&utm_medium=email.

${ }^{40}$ AfDB, 2018. African Economic Outlook 2018. Available at: www.afdb.org/fileadmin/uploads/ afdb/Documents/Publications/African_Economic_Outlook_2018_-_EN.pdf, see Chapter 3. [Online], pp. 63-93.

${ }^{41}$ Jayaram, K., Kassiri, O., and Sun, I. Y., 2017. The Closest Look Yet at Chinese Economic Engagement in Africa. [Online] Available at: www.mckinsey.com/featured-insights/middle-east-and-africa/theclosest-look-yet-at-chinese-economic-engagement-in-africa.
} 
loans have also hardened of late. ${ }^{42}$ A number of other African countries have subsequently followed suit in allowing the renminbi as a trading currency.

To safeguard its growing investments in Africa, China has also expanded its direct and indirect role in peace and security in Africa, similar to Europe and the USA some decades previously. In addition to a naval base in Djibouti, the inaugural China-Africa Defence and Security Forum held in June/July 2018 established the overarching framework for China's security programs in Africa. In February 2019 China announced that it had provided the US $\$ 180$ million to fund peace and security efforts in Africa and it is already the largest supplier of weapons to Sub-Saharan Africa. China's role in support of the African Union and numerous African armed forces is therefore steadily expanding as does its efforts at mediation. ${ }^{43}$

Although there is a dearth of data about the precise nature and scale of China's investments and overseas lendings, including in Africa, ${ }^{44}$ there is a clear danger that through the combined impact of China and others, a number of African countries could again find themselves in a debt trap as discussed in Chapter 2. Already, in January 2019, the International Monetary Fund assessed that about 17 low-income African countries were either in or at risk of debt distress or close to one and, in April 2020, the G20 countries, the IMF and the World Bank announced a first COVID-19 related debt standstill for low-income countries. ${ }^{45}$

The third, and much smaller flow of external funds to Africa is through remittances.

\footnotetext{
${ }^{42}$ Kazeem, Y., 2018. Nigeria Has Taken Its First Steps in Adopting China's Yuan as a Reserve Currency. [Online] Available at: https://qz.com/africa/1346766/chinas-yuan-trades-in-nigeria-africatop-economy/.

${ }^{43}$ Nantulya, P., 2019. Chinese Hard Power Supports Its Growing Strategic Interests in Africa. [Online] Available at: https://africacenter.org/spotlight/chinese-hard-power-supports-its-growing-strategic-int erests-in-africa/?utm_source $=$ Media + Review + for + January $+22 \% 2 \mathrm{C}+2019 \& u t m \_$campaign $=$Media + Rev iew+for+January+22\%2C+2019\&utm_medium=email.

${ }^{44}$ Reinhart, C. H., 2018. Exposing China's Overseas Lending. [Online] Available at: www.project-syn dicate.org/commentary/china-opaque-foreign-development-loans-by-carmen-reinhart-2018-10?barrier= accesspaylog. Large portions of Chinese (and other) grants and investment in Africa is opaque while many African countries abet this unhealthy situation through lack of open, competitive tendering processes and lack of legislative oversight of public spending, amongst others.

${ }^{45}$ International Monetary Fund, 2018. Regional Economic Outlook. Sub-Saharan Africa, Washington: Monetary Fund.
} 


\section{Remittance Flows to Africa}

Data on remittances needs to be treated with care: such flows mostly occur through informal channels and are driven by the size of the migrant population for which data is equally unreliable. Different from aid and FDI, remittance flows do not affect government revenues since they generally consist of money sent home by migrants, and serve to support the livelihoods of poor families. 46

Generally migrants have a positive economic impact in hosting countries and are often less likely to be involved in crime. According to the IMF, each one percent increase in the share of migrants in the adult population of advanced economies can increase the GDP per capita by up to two percent in the long term. But anti-migrant sentiments have become an important domestic policy issue in most Western countries as well as in countries like South Africa. ${ }^{47}$

The average annual growth figure for remittances is at around five percent. Nigeria (at US\$22.3 billion in 2017), with its large diaspora, is the largest recipient of remittances in Africa. ${ }^{48}$ As a percentage of GDP Liberia is the biggest recipient of remittances (at 26\%). ${ }^{49}$

The IFs Current Path forecast is that remittance flows to Africa will remain constant at around US\$50 billion per annum to 2040 .

Remittances have benefited from new technologies that have lowered the costs of sending small amounts of money privately from one country to another, but the impact of the war on terror and concerns about money flows to groups and individuals associated with terrorists have created numerous obstacles for Africans to send money home. Furthermore, it still costs more

\footnotetext{
${ }^{46}$ African migrants (including refugees, regular and illegal migrants, short and long-term migrants, etc.) represent about $14.1 \%$ (or 36.3 million) of the global migrant population. An estimated ninetenths of African migrants stay within the continent, moving to neighbouring countries or elsewhere within their region. Most are in Côte d'Ivoire, Uganda, South Africa, South Sudan and Burkina Faso. The EU hosts nine million African migrants, consisting of an estimated five million from North Africa (most from Algeria and Morocco in France, and Moroccans in Spain) and four million from Sub-Saharan Africa. In the Middle East, most African migrants are from Egypt and to be found in Saudi Arabia and the United Arab Emirates. Mo Ibrahim Foundation, 2019. Africa's Youth: Jobs or Migration?, London: Mo Ibrahim Foundation, pp. 13-15.

${ }^{47}$ World Bank Group, 2017. Migrations and Remittances: Recent Developments and Outlook. Special Topic. Return Migration. Migration and Development Brief 28, October 2017, p. 10.

${ }^{48}$ Remittance flows in North Africa mostly go to Egypt (at US\$18.2 billion). Other large recipients are Morocco (at US $\$ 7.1$ billion) and Senegal (US\$2.3 billion) followed, in declining order of importance, by Algeria, Ghana, Tunisia, Kenya, Uganda, Mali, Ethiopia, South Africa, Liberia and Burkina Faso (at US $\$ 0.5$ billion). Ibid. Box on pp. 25 and 28.

${ }^{49}$ Followed by Comoros, The Gambia, Senegal, Cape Verde, Togo, Mali, Morocco, Nigeria, São Tomé and Príncipe, Tunisia, Egypt (5\%), Djibouti and Algeria (1.1\%) Ibid. Box on pp. 25 and 28.
} 
to remit money to Sub-Saharan Africa than any other region globally. Moving money between neighbouring African countries is even more expensive. ${ }^{50}$

\section{Modelling Increased FDI, Aid and Remittances: The External Support Scenario}

In this section I model the impact of an External Support scenario on the continent's medium to long-term development trajectory consisting of modest increases in aid, FDI and an increase in remittances.

Against the backdrop of a global focus on the achievement of the SDG's by 2030, and the impact of COVID-19, the aid component of the External Support scenario envisions an increase in the amount of development aid to Africa in the run-up to the 2030 target year that then modestly tapers down by 2040. In the External Support scenario Africa would receive a total of US $\$ 137$ billion more aid (cumulatively over the forecast horizon) than in the Current Path forecast. ${ }^{51}$ Instead of US $\$ 102$ billion aid in 2030, the final year of the SDGs, Africa would get US\$115 billion. Most of the additional funds would go to low-income countries.

The intervention in the External Support scenario increases the levels of FDI inflows to $4.6 \%$ of GDP by 2040 (instead of 3.9\% in the Current Path).

Such inflows would only be possible with improved levels of stability and policy certainty, but would still constitute a relatively small portion of global FDI flows.

The final intervention is on remittances.

The IFs Current Path forecast is that remittances will drop from $1.6 \%$ of GDP in 2020 to $0.6 \%$ by 2040 as the size of African economies increases. This translates into an increase from the current estimate of US\$49 billion in the Current Path forecast to US $\$ 75$ billion by 2040 in the External Support scenario. The largest portion of the increase in remittances goes to Nigeria, followed by Egypt, Morocco, Ghana, Senegal, Tunisia, Somalia, Libya and Lesotho.

Figure 14.1 presents the contribution from remittances, aid and FDI in the Current Path compared to the External Support scenario for 2020, 2030 and 2040. It shows the extent to which remittances generally remain flat in absolute terms. Aid amounts increase but the bulk of increases comes from FDI. Whereas the three sources of funds contribute roughly equal amounts in

\footnotetext{
${ }^{50}$ Ibid., p. 5.

${ }^{51}$ At its peak in 2030 Africa would receive US\$113.3 billion instead of US\$100.1 billion.
} 


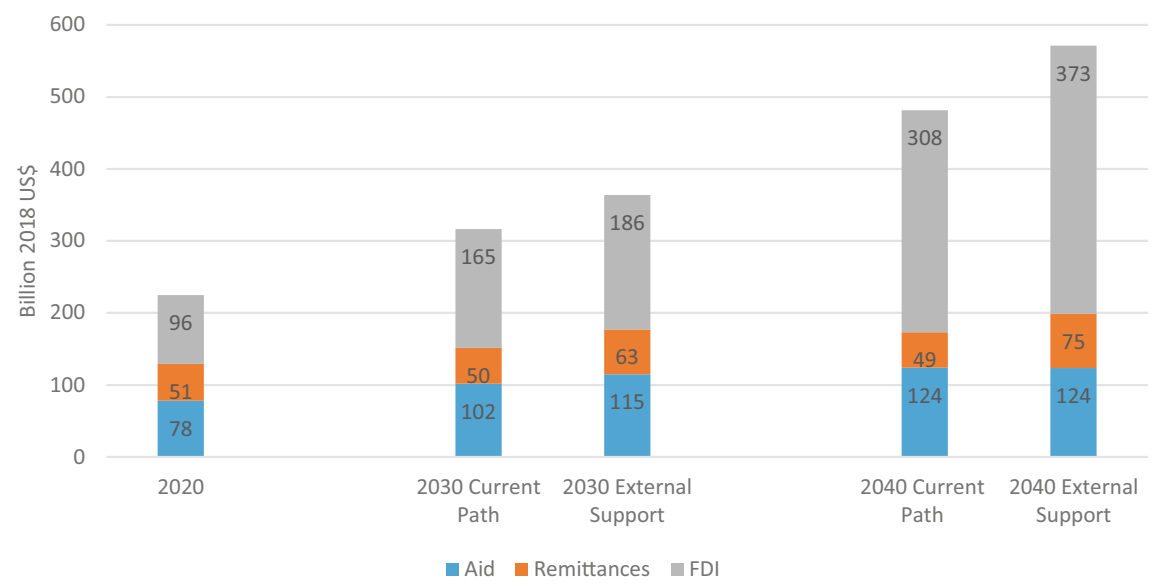

Fig. 14.1 Contribution of remittances, aid and FDI in 2020, 2030 and 2040: Current Path vs External Support scenario (Source IFs version 7.45 initialising from IMF World Economic Outlook 2017 and other sources)

2020, by 2040 FDI contributes nearly twice as much as aid and remittances combined in the External Support scenario. In the External Support scenario the increase in aid to 2030 reverts to the Current Path forecast by 2040.

The financial pool from which FDI is able to draw is so large that it necessarily needs to be prioritised as a source of growth and development for Africa. Hence the importance of measures such as trade facilitation (through Aid for Trade and other measures), ease of doing business and efforts to establish Special Economic Zones as vehicles to attract FDI, all of which were discussed in Chapter 8.

\section{The Impact of the Combined External Support Scenario}

By 2040, Africa benefits from a total additional inflow of almost US $\$ 90$ billion in the External Support scenario compared to the Current Path forecast for that year-the difference in the columns' height for the Current Path and External Support in Fig. 14.1. The majority of aid goes to low-income countries (where most poor people are), remittances are spread across countries in line with historical levels and most FDI goes to upper-middle-income countries.

The combined impact of the External Support scenario is to increase total government revenues in Africa by US $\$ 47$ billion in 2040. The cumulative 
increase in government revenues from 2020 to 2040 is much more impressive, amounting to US $\$ 463$ billion. Although the interventions in all three areas are aggressive, the impact of FDI is significantly larger than that from aid and remittances as its contribution grows much more rapidly than that of the others, as is reflected in Fig. 14.1.

The increase in government revenues translates into tangible outcomes, although generally only towards the end of the forecast horizon. For example, in 2040 African governments consumption on education would increase by US\$9 billion and by US\$5 billion above the Current Path forecast.

Increased external support means that the total Africa economy is US $\$ 174$ billion larger in 2040 than it otherwise would have been and that GDP per capita increases by US $\$ 112$.

Beyond these findings the External Support scenario reminds that more aid, although important, would only modestly reduce extreme poverty in Africa. By 2030 the External Support scenario reduces the number of Africans living in extreme poverty (using US $\$ 1.90$ ) by only two million. By 2040 the number has increased to 16 million, of which two-thirds are in low-income countries. That is in spite of the fact that the bulk of additional aid goes to low-income countries, where most extremely poor people are to be found.

\section{Conclusion: Unlocking Foreign Assistance}

China's footprint in Africa has grown enormously in recent years, but Europe and the EU in particular remain Africa's most important partner in trade, stock of FDI and aid. For the 2017-2020 External Investment Plan the EU budgeted $€ 32.5$ billion in grants to Africa and, in its 2021-2027 budget, it provides for $€ 40$ billion. In addition, the EU budgeted for $€ 3.7$ billion in grants for blending and guarantees in its current plan. These amounts exclude bilateral aid from individual EU member states. ${ }^{52}$

Looking eastward, the Belt and Road Initiative will connect China with the resources for growth and development with a large potential future market while Chinese peacekeepers and arms help to secure its investments. At the same time Africa needs to realise that the focus of the Belt and Road Initiative is largely on connecting China to its immediate neighbourhood in Asia and its impact in Africa is likely to be limited. In fact, Africa may already have experienced peak Chinese interest and may increasingly have to look elsewhere for future investment growth.

\footnotetext{
${ }^{52}$ European Commission, 2018. Africa-Europe Alliance. [Online] Available at: https://ec.europa.eu/ commission/africaeuropealliance_en.
} 
The claim of the demise of aid is still premature and, together with remittances, aid will remain important for many poor African countries into the future. The growth of private capital flows from outside Africa has benefited only a few countries although it will grow in importance. African countries will have to learn to manage the associated volatility. Generally FDI is conservative and follows rather than leads other sources of investment. FDI generally tracks investment decisions by locals and requires policy stability.

Remittances have become significantly more important for some countries but its impact is limited. Eventually infrastructure development in Africa will largely depend upon investment decisions from its own governments that need to focus on sectors and segments (such as water and sanitation infrastructure) for which other financiers have little appetite.

That said, the continent needs to work much harder to unlock investment from the wall of money searching for returns in Europe, North America, China and eventually India, although short-term prospects in the light of COVID-19 is necessarily poor. FDI boosts economic growth and is key in contributing to knowledge transfer and hence to Africa's economic transformation. But the inadequate technical, governance and implementation capacity in African countries requires a dedicated effort to strengthen domestic legislation, institutions and policies governing investment as well as its ability to negotiate and oversee the associated agreements. If the international community wants to help Africa it needs to incentivise private investment in Africa through tax benefits, de-risking foreign investment and building African capacity to negotiate, manage and evaluate projects.

The rise of China is certainly the most noteworthy feature of the twentyfirst century and its demand for natural resources played a big part in the story of Africa's growth for several decades from the mid-1990s. This is also evident from the extent to which commodity exports from Africa increased more rapidly than the global average (see Fig. 11.1 in Chapter 11). As a result Africa's broad pattern of increased dependence on commodity exports to earn foreign exchange and continued deindustrialisation from already low levels has continued unabated. In the meanwhile the Chinese economy is rebalancing and its once insatiable appetite for commodities has tempered. As the hubris around the Belt and Road Initiative calms down China has limited interest to maintain the breakneck speed of investment growth in Africa that has been evident over the last two decades.

Africa should therefore not rely only on China's hunger for raw materials, its loans and future investment in infrastructure projects. In fact, China is itself concerned about the viability of African governments to service loans and, at the 2018 Forum on China-Africa Cooperation meeting in Beijing, 
scaled back its forecast of future partnership with Africa, expressed its concern about rising debt levels, noted that projects need to be subject to cost-benefit analysis and warned that it intends to pull back on vanity projects. ${ }^{53}$

If China stumbles, it would have a massive impact on Africa. According to Bloomberg, China's credit boom has been 'the largest factor driving global growth' in the decade from 2010, and debt is rising fast. ${ }^{54}$ Over the same period, China's debt-to-GDP ratio has risen from about $140 \%$ to more than $250 \%$. China has defied expectations before, but it is unlikely to do so indefinitely. In an important recent book Nicholas Lardy recently argues that China's growth prospects are now being shadowed by the spectre of resurgent state domination. ${ }^{55}$ Whereas China's private sector is responsible for much of its economic growth, the attention has shifted to ailing, underperforming and indebted state-owned companies. Inefficiencies are therefore mounting. Additionally, the country has a debt problem that was accelerated by the large stimulus project that Beijing launched in response to the global financial crisis in 2008. Normally countries experience growth problems when the GDP to debt ratio is in excess of $60 \%$. Chinese debt, now at more than $250 \%$ of GDP, may already be responsible for a loss of up to two percentage points of economic growth, opines Lardy.

Looking to the future, Africa has significant scope to improve matters by investing in the capacity of its institutions to oversee and manage trade, FDI, aid and develop formal remittance processes. The source of aid and investment support is eventually less important except to ensure that African countries are not forced to choose particular alliances as happened during the Cold War but rather encourage collaboration and mix-and-match. In this vein the recent trend in funding large projects is towards so-called basket funding that may include various partners such as from the World Bank, the African Development Bank, the European Investment Bank and the Bank of China-and where project implementation is a collaborative venture that may involve a German engineering company to oversees technical compliance, American project management and Chinese construction capacity to do the heavy lifting.

\footnotetext{
${ }^{53}$ Staff Reporter, 2019. China’s Xi Offers Another $\$ 60$ Billion to Africa, But Says No to 'Vanity' Projects. Reuters [Online], 3 September 2018. Available at: www.reuters.com/article/us-china-africa/ chinas-xi-offers-another-60-billion-to-africa-but-says-no-to-vanity-projects-idUSKCN1LJ0C4.

${ }^{54}$ Orlik, T., Chen, F., Wan, Q., and Jimenez, J., 2018. Sizing Up China's Debt Bubble: Bloomberg Economics. [Online] Available at: www.bloomberg.com/news/articles/2018-02-08/sizing-up-china-sdebt-bubble-bloomberg-economics.

${ }^{55}$ Lardy, N. R., 2019. The State Strikes Back the End of Economic Reform in China? Washington: Peterson Institute for International Economics.
} 
Eventually there is little difference between Africa's old and new partners. Each inevitably put their own interests first, as should Africa. But this time around Africans should work more diligently in setting the terms for how best it can benefit from aid, FDI and the flow of remittances. Africa needs to become a rule-maker and assume a larger role in its own destiny, particularly in the mode of development that it pursues.

The West and China have developed and industrialised at the cost of others in terms of the impact on the global climate. Africa, the region that will be the development latecomer has little option but to pursue a different pathway, namely that of sustainable and green development, the topic of the next chapter.

\section{Further Reading}

Addison, Tony, Morrisey, Olver, and Tarp, Finn. 2017. The Macroeconomics of Aid: Overview. The Journal of Development Studies, 53(7), pp. 987-997. https://doi. org/10.1080/00220388.2017.1303669.

Duggan, William, and Hubbard, Glenn. 2009. The Aid Trap: Hard Truths About Ending Poverty. Columbia University Press.

Moyo, Dambisa. "Dead Aid: Why Aid Is Not Working and How There Is a Better Way for Africa."

Watkins, Kevin. 2009. Why Dead Aid Is Dead Wrong. Huffington Post. www.huf fpost.com/entry/why-idead-aidi-is-dead-wr_b_191193.

Open Access This chapter is licensed under the terms of the Creative Commons Attribution 4.0 International License (http://creativecommons.org/licenses/by/4.0/), which permits use, sharing, adaptation, distribution and reproduction in any medium or format, as long as you give appropriate credit to the original author(s) and the source, provide a link to the Creative Commons license and indicate if changes were made.

The images or other third party material in this chapter are included in the chapter's Creative Commons license, unless indicated otherwise in a credit line to the material. If material is not included in the chapter's Creative Commons license and your intended use is not permitted by statutory regulation or exceeds the permitted use, you will need to obtain permission directly from the copyright holder.

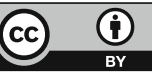

